\title{
PERANCANGAN KOLEKSI PA'SURRA TORAYA SEBAGAI SELFSTATEMENT GAYA HIDUP WANITA URBAN
}

\author{
Fei Sien Jesica, Dewi Isma Aryani, Peter Muljono \\ (Email: f.sien@yahoo.com) \\ Program Studi D-III Seni Rupa dan Desain \\ Fakultas Seni Rupa dan Desain \\ Universitas Kristen Maranatha \\ Jl. Prof.drg. Suria Sumantri, MPH no. 65, Bandung, Indonesia.
}

\begin{abstract}
ABSTRAK
Beragam kebudayaan Nusantara, salah satunya ukiran Suku Toraja telah menjadi inspirasi perancangan koleksi busanaready-to-wear deluxeyang berjudul "Pa'surra Toraya". Melalui koleksi Pa'surra Toraya ini, ukiran Suku Toraja yaitu Pa'tedong dan Pa'sekong Kandaure dikemas dalam bentuk yang modern sehingga dapat diterima di kalangan masyarakat urban, khususnya wanita.Koleksi Pa'surra Toraya bersiluet dasar memberikan kesan etnik bagi penyuka busana dengan unsur desain yang terinspirasi dari busana adat Suku Toraja. Motif ukiran Suku Toraja pun diaplikasikan pada busana melalui teknik print, beads (payet), dan sablon flocksebagai penguat kesan etnik. Koleksi ready-to-wear deluxe Pa'ssura Toraya ditujukan bagi masyarakat, khususnya wanita kalangan menengah ke atas dengan rentang usia 25-40 tahun yang berkarakter cerdas, elegan, memiliki mobilitas tinggi, dan menghargai budaya lokalsebagai penunjang busana pada acara semi-formal.
\end{abstract}

Kata kunci: etnik; modern; payet; sablon flock; ukiran Toraja

\begin{abstract}
Indonesia's cultural diversification, including the Toraja carving, has inspired the design of ready-to-wear deluxe fashion collection entitled "Pa'surra Toraya". Through the collection, Toraja carving, Pa'tedong and Pa'sekong Kandaure, are presented in a modern form acceptable among urban communities, especially women. Pa'su rra Toraya collection silhouette gives the ethnical impression for the enthusiasts of fashion with design elements inspired by Toraja traditional clothing. Toraja carving motif is applied to the clothing through print technique, beads (sequins), and flock screen-printing to reinforce the ethnic impression. The ready-to-wear deluxe collection, Pa'ssura Toraya, is intended for the public, especially the upper middle class women, 25-40 years old, characterized as smart, elegant, high-mobilized individuals who appreciate the local culture as a supporting fashion in semi-formal events.
\end{abstract}

Keywords: engraving Toraja; ethnic; flock printing; modern; sequins 


\section{PENDAHULUAN}

Indonesia merupakan salah satu negara dengan kebudayaan yang beraneka ragam. Kebudayaan tersebut tertuang dalam berbagai unsur, yaitu kesenian, sistem teknologi, sistem organisasi masyarakat, bahasa, sistem ekonomi, dan sistem pengetahuan. Kebudayaan juga tertuang dalam berbagai bentuk, salah satunya dalam bentuk ukiran. Terdapat banyak ukiran yang menjadi ciri khas dan kebanggaan setiap daerah. Salah satu kebudayaan Indonesia yang memiliki ukiran dengan corak khas adalah suku Toraja. Suku Toraja adalah suku yang menetap di pegunungan bagian utara Sulawesi Selatan, Indonesia. Populasinya diperkirakan sekitar satu juta jiwa, dengan sekitar 500.000 penduduk di antaranya masih tinggal di Kabupaten Tana Toraja, Kabupaten Toraja Utaradan Kabupaten Mamasa (http://www.tanatorajakab.go.id/id /con tent/letak-geografis/2015).

Pada awalnya Bahasa Toraja hanya diucapkan dan tidak memiliki sistem tulisan. Untuk menunjukkan konsep keagamaan dan sosial, suku Toraja membuat ukiran kayu dan menyebutnya Pa'ssura yang berarti 'tulisan'. Oleh karena itu, ukiran kayu merupakan perwujudan budaya Toraja.

Konsep perancangan busana Pa'ssura Toraya yang terinspirasi dari budaya ukiran Suku Toraja diangkat dari ukiran Pa'tedong dan Pa'sekong Kandaure. Pa'tedong berasal dari kata Tedong yang dalam Bahasa Toraja berarti kerbau. Di Toraja, kerbau adalah binatang peliharaan yang utama dan sangat disayangi.Kerbau bagi masyarakat Toraja mempunyai fungsi ganda yaitu sebagai emas kawin, pengolah sawah, korban persembahan kepada dewa leluhur, dan melambangkan tulang punggung kehidupan dan kemakmuran.Filosofi kemakmuran itu sendiri adalah kerbau yakni salah satu hewan yang menunjukkan kedudukan atau simbol status sosial. Pa'sekong Kandaure adalah ukiran yang menyerupai anyaman perhiasan bernama Kandaure.Sekong artinya patahan ukiran itu, sedangkan Kandaure berarti perhiasan yang serupa kukusan nasi dengan pangkalnya terbuat dari manik-manik.Kandaure adalah perhiasan dengan harga yang sangat mahal, setara dengan 12 ekor kerbau.Filosofi Pa'sekong Kandaure melambangkan keturunan yang selalu hidup dalam kebahagiaan bagaikan cahaya bagi kehidupan Suku Toraja(http://www.torajaparadise.com/kajian-antropologis-suku-torajasebuah.html/2015). 
Adapun permasalahan yang ditemukan dalam penelitian ini adalah:

Bagaimana cara yang tepat untuk mengangkat motif ukiran Toraja melalui koleksi busana ready-to-wear deluxe yang berkarakter etnik modern bagi kalangan masyarakat urban?

Batasan yang ditentukan dalam perancangan ini dibatasi pada:

1. Tema besar perancangan yaitu motif ukiran Toraja yang digabungkan dengan tren Vigilant dan subtema Numericraft. Motif ukiran yang diangkat yaitu Pa'tedong dan Pa'sekongKandaure. Pa'tedong melambangkan tulang punggung kehidupan dan kemakmuran. Pa'sekong Kandaure melambangkan keturunan yang selalu hidup dalam kebahagiaan bagaikan cahaya bagi kehidupan Suku Toraja.

2. Material yang digunakan yaitu kainjenis tafetta bridal silk. Siluet basic shape busana cenderung simple, memiliki polacutting $\mathrm{H}$ line, terdapat unsurasimetrisdan simetrisyang terinspirasi dari busana tradisionalSuku Toraja. Warna-warna yang dipakai dalam busana yaitu merah, kuning, putih, dan hitam sebagai lambang kehidupan Suku Toraja.

3. Teknik print,beads(payet), dan sablon flock diterapkan untuk menampilkan motif ukiran Suku Toraja pada kain.

4. Target market yang dituju yaitu wanita urban berusia 25-40 tahun kalangan menengah keatas dengan gaya hidupsosialitamodern, memiliki mobilitas tinggi, berwawasan luas, dan menghargai kebudayaan lokal.

\section{METODE PENELITIAN}

Perancangan dibuat berdasarkan penelitian yang dilakukan dengan metode kualitatif berupa observasi lapangan dan kajian telaah buku Trend Forecasting 2017/2018Grey Zone, dengan tema yang diangkat yaitu Vigilant dan subtema Numericraft.

Teori-teori yang digunakan dalam penelitian ini sebagai studi literature dari perancangan ini antara lain:

1. Teori busana, untuk memaparkan kaitan penelitian ini dengan pakaian adat

2. Teori warna, terkait dengan penggunaan warna pada motif Toraja 
Adapun warna yang digunakan dalam perancangan ini terinspirasi dari warna ukiran Suku Toraja yaitu: hitam, putih, merah, dan oranye-kuning. Warna-warna tersebut mempunyai arti khusus bagi masyarakat Suku Toraja itu sendiri. Warna hitam melambangkan kematian atau kegelapan yang akan menjadi akhir kehidupan manusia di bumi sebelum memulai perjalanan menuju kahyangan. Warna merah dan putih melambangkan kehidupan manusia yang diberkati oleh Tuhan.

Berdasarkan ringkasan landasan teori tentang busana dan kebudayaan yang ada pada suku Toraja di atas, maka dapat ditampilkan melalui image board sebagai berikut:

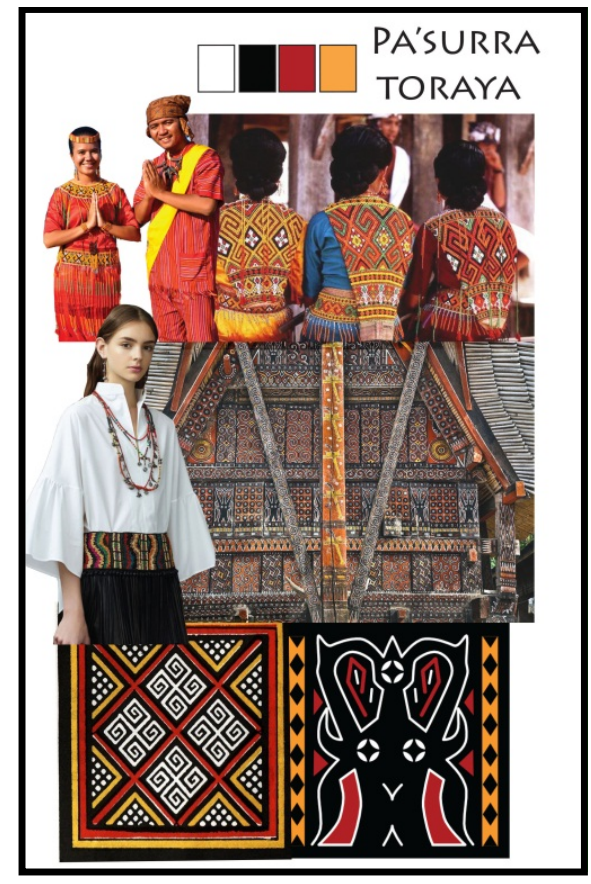

Gambar 1. Image Board

Sumber: dokumentasi penulis, 2016

\section{PEMBAHASAN}

Kajian telaah tentang tren fesyen diambil dari buku Trend Forecasting 2017/2018 Grey Zone. Grey Zone dinamakan sebagai visualisasi dari sebuah masa, yakni manusia kehilangan kemampuan untuk membedakan yang benar dan salah atau hitam dan putih. Peleburan batas antara hitam dan putih, standar penilaian beralih kepada subyektivitas pembuat keputusan.

Meski didominasi oleh kegelapan, dengan kebenaran atau kesalahan menjadi suatu yang relatif abu-abu, namun bukan berarti tidak ada warna atau harapan yang mungkin muncul akibat adaptasi kemanusiaan terhadap kecerahan harapan dan stabilitas sistem kehidupan. Dalam 
buku Grey Zone sendiri membagi empat tema besar di dalamnya, yaitu: Archean, Vigilant, Cryptic, dan Digitarian.

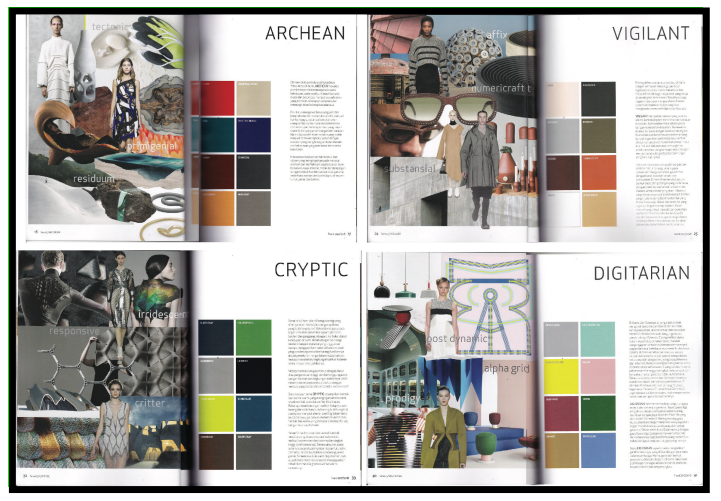

Gambar 2. Buku Grey Zone

Sumber: Buku Trend Forecasting Grey Zone 2017/2018

Tema Vigilant menceritakan tentang paduan yang selaras antara kerinduan masa lalu dan tuntutan masa kini, kemewahan manual berpadu dengan kemewahan digital, sedangkan subtema Numericraft diangkatl karena adanyakonsistensi tekstur dansiluet basic shape yang ditampilkan.

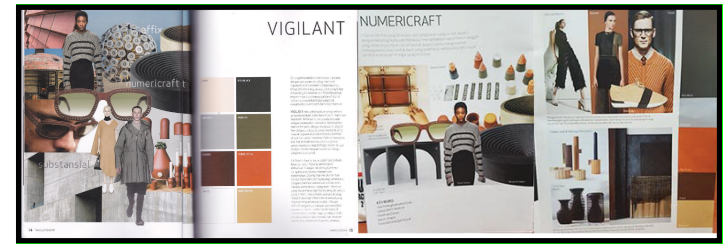

Gambar 3. Tema dan subtema terpilih

Sumber: Buku Trend Forecasting Grey Zone 2017/2018

Istilah busana berasal dari Bahasa Sansekerta yaitu bhusana, yang kemudian populer dalam Bahasa Indonesia menjadi busana berarti pakaian (http://www.kelasbusana.com/2016/01/peng ertian-busana-jenis-dan-fungsinya.html).

Pengertian busana dalam arti luas adalah segala sesuatu yang dipakai mulai dari kepala sampai dengan ujung kaki yang memberi kenyamanan dan menampilkan keindahan bagi si pemakai (Ernawati, 2008: 24). Busana adalah suatu kesatuan yang terdiri dari pakaian, aksesoris, dan berbagai tambahan yang membuat penampilan seseorang menjadi sempurna.

Pakaian adat merupakan pakaian resmi suatu daerah. Sedangkan adat merupakan suatu 
peraturan atau ketentuan yang dilaksanakan dari generasi-generasi, baik berupa peraturan turun-temurun maupun suatu peraturan yang dibuat berdasarkan norma yang berlaku (http://tekateki1234.blogspot.co.id/2015/07/pakaian-adat.html/2016).

Di lain pihakPringgodigdo (dalam Sahriah Muhammading, 1997 : 16) menyebutkan adat adalah aturan-aturan tentang beberapa segi kehidupan manusia yang tumbuh dari usaha dalam suatu daerah tertentu di Indonesia sebagai kelompok sosial untuk mengatur tata tertib tingkah laku masyarakat.

Pakaian adat suku Toraja terbagi menjadi 2 macam yakni pakaian adat pria dan pakaian adat wanita.Pakaian adat pria Toraja dikenal dengan Seppa Tallung Buku, berupa celana yang panjangnya selutut.Pakaian ini masih dilengkapi dengan aksesori lain, seperti Kandaure, Lipa', Gayang, dan sebagainya.Sedangkan baju adat wanita Toraja disebut Pokko, berupa baju dengan lengan yang pendek.Warna kuning, merah, dan putih adalah warna yang paling sering mendominasi pakaian adat Toraja.Baju adat Kandore yaitu baju adat Toraja yang berhiaskan manik-manik berfungsi sebagai penghias dada, gelang, ikat kepala, dan ikat pinggang (http://www.budaya-indonesia.org/Pakaian-Adat-Suku-Toraja/ 2016).

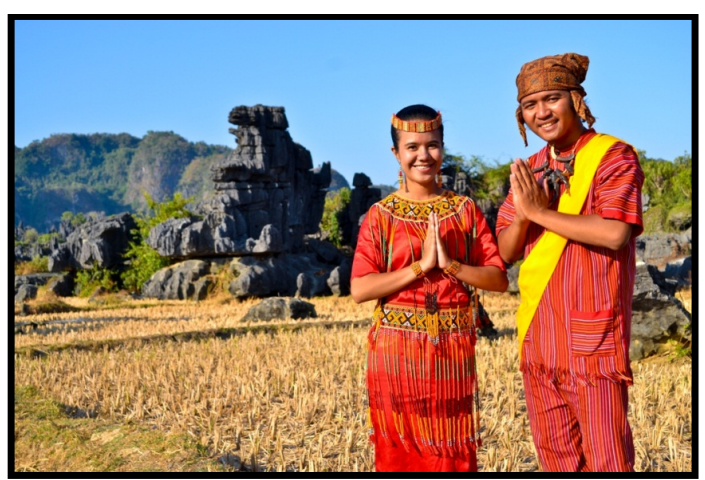

Gambar 4. Pakaian adat Toraja Sumber:http://3.bp.blogspot.com/_4nWIdTU/Peta+Toraja.JPG diakses pada 11November 2016 pk. 17:09 WIB

Selain pakaian, ukiran yang dimiliki oleh Toraja juga menampilkan ciri khas tersendiri.Ukiran suku Toraja dibuat menggunakan alat ukir khusus yang ditempatkan di atas sebuah papan kayu, tiang rumah adat, jendela, atau pintu. Bukan asal ukiran, setiap motif ukiran dari Toraja memiliki nama dan makna khusus. Keteraturan dan ketertiban merupakan ciri umum dalam ukiran kayu Toraja.Ukiran Toraja memiliki sifat abstrak dan berwujud geometrik.Tumbuhan dan 
hewan sering dijadikan dasar dari pembuatan ornament ukiran Toraja.

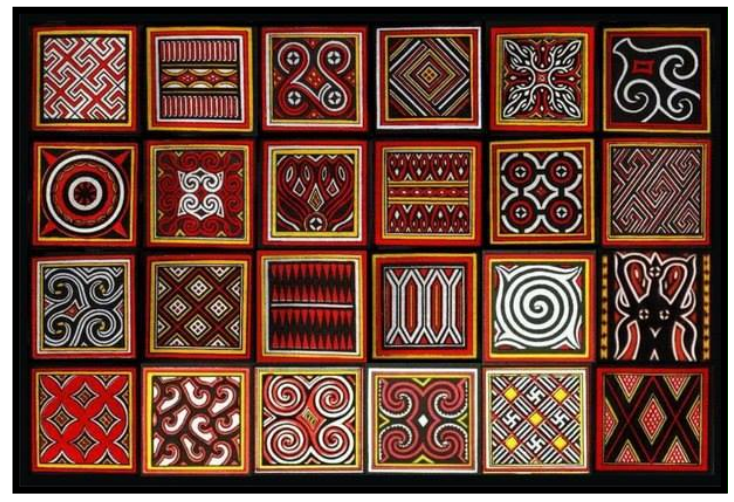

Gambar 5. Motif ukiran Toraja

Sumber: http://asryines.student.umm.ac.id/wp-content/uploads/sites/19815/2016/06/14239882041813918563.jpg diakses pada 11 November 2016 pk. 17:09 WIB

Perancangan koleksi busana ready-to-wear deluxe Pa'surra Toraya ini memiliki empat tampilan (looks).Busana yang dirancang memiliki aplikasi unsur ilustrasi dari motif ukiran Suku Toraja.Ilustrasi motif ukiran Toraja diterapkan di setiap tampilan busana.Secara keseluruhan bahan yang digunakan adalah taffeta bridal berwarna putih, dimaksudkan untuk memudahkan penyesuaian warna yang diinginkan menggunakan teknik digital printing.Koleksi busana Pa'Surra Toraya menggunakan tiga teknik, yaitu printing, beads, dan flock.Teknik printingdigunakan untuk menggambarkan ilustrasi dan menunjukkan warna dari ukiran Toraja. Teknik penambahanbeads digunakan untuk memberikan kesan 3D sebagai aksen focal point busana. Dan teknik sablonflock digunakan untuk menampilkan tekstur pada kain dengan menerapkan motif ukiran Toraja.

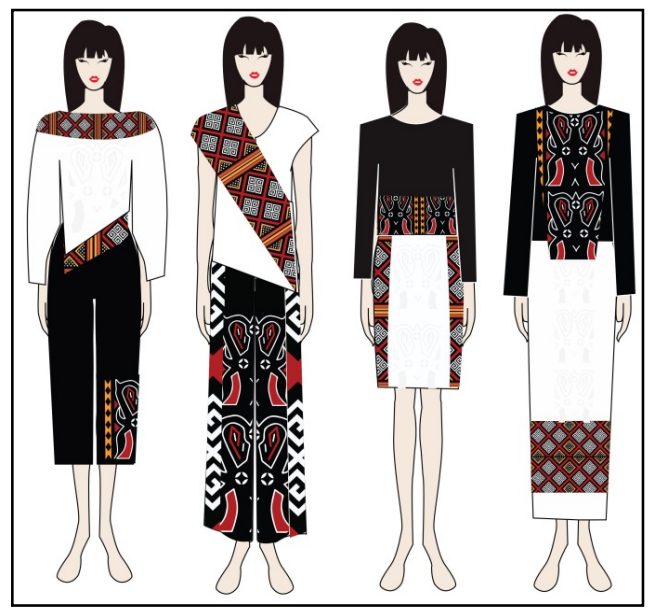

Gambar 6. Desain koleksi busana tampak depan Sumber: dokumentasi penulis, 2016 


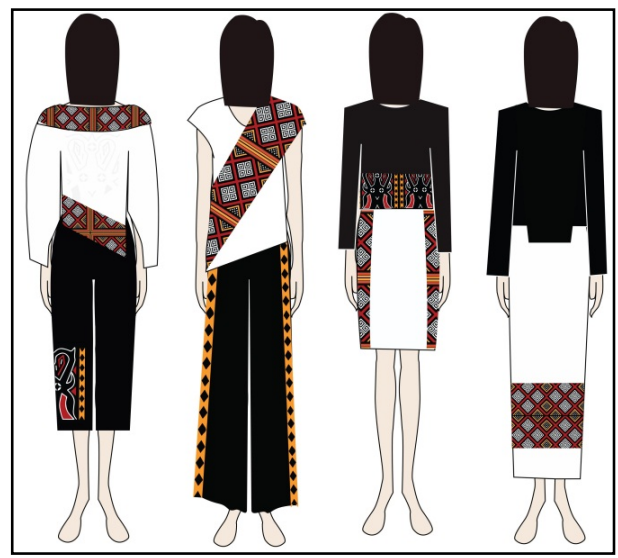

Gambar 7. Desain koleksi busana tampak belakang Sumber: dokumentasi penulis, 2016

Perancangan detail pada busana terdiri dari motif ukiran Suku Toraja dan aksesori pada koleksi Pa'surra Toraya berupa sepatu sandal. Proses perancangan desain yang dibuat melalui proses printing, sablon flock, dan beads diterapkan pada motif yang ada pada busana. Proses pembuatan motif Pa'sekong Kandaure dan Pa'tedong menggunakan program Adobe Illustrator. Penerapan printing gambar pada busana melalui proses pola dan visualnya dibuat dengan hasil scan menggunakan Adobe Illustrator, kemudian motif ukiran Pa'sekong Kandaure dan Pa'tedong diletakkan pada posisi yang telah ditentukan.

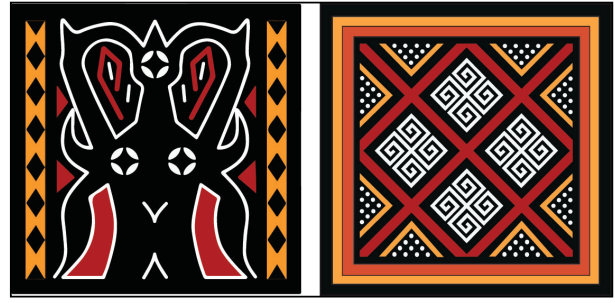

Gambar 8. Desain motif Pa'sekong Kandaure dan Pa'tedong Sumber: dokumentasi penulis, 2016

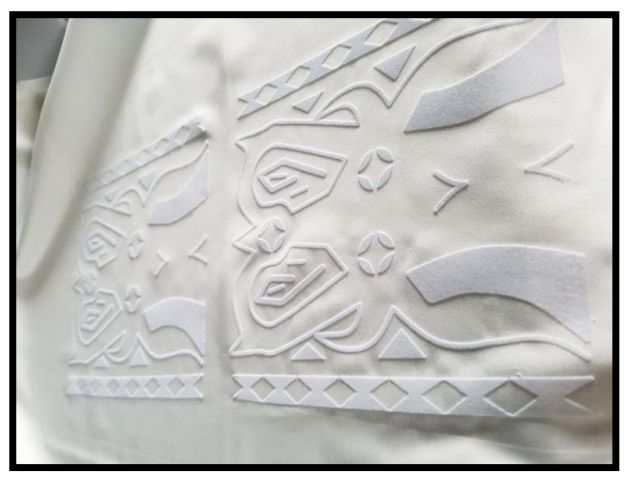

Gambar 9. Hasil sablon flock motif Pa'tedong Sumber: dokumentasi penulis, 2016 
Teknik penjahitan beads (payet) dapat memberikan manfaat berupa technocraft dan craftsmanship. Pengaplikasian teknik ini menambah kesan unik dan mewah pada busana melalui beads berbentuk bulir berwarna merah, kuning, hitam, dan putih.

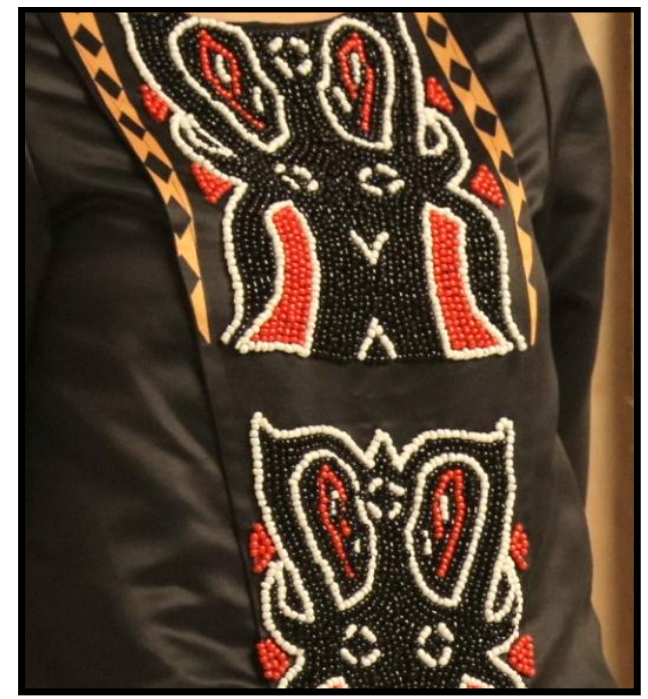

Gambar 10. Hasil teknik beads motif Pa'tedong Sumber: dokumentasi penulis, 2016

\section{Tampilan Desain I}

Tampilan pertama terdiri dari dua potong busana yaitu atasan dan celana panjang $7 / 8$.Secara keseluruhan bahan yang digunakan adalah 454abrina bridal.Atasan berupa model 454abrina dengan pola tangan panjang raglan.llustrasi potonganmotif ukiran Pa'sekong Kandaure ditempatkan pada bagian atas dada menyerupai 454abrina dan ditempatkan pada potongan bawah membentuk pola asimetris.Selain itu, terdapat motif Pa'tedong yang disablon flock ditempatkan di bagian tengah atasan.

Celana panjang memiliki potongan lurus 7/8.Celana dibuat dari bahantaffeta bridal, aplikasi warna diperoleh dari teknik digital printing berwarna hitam.llustrasi Pa'tedong ditempatkan di bawah celana dengan tambahan beads pada motif. 


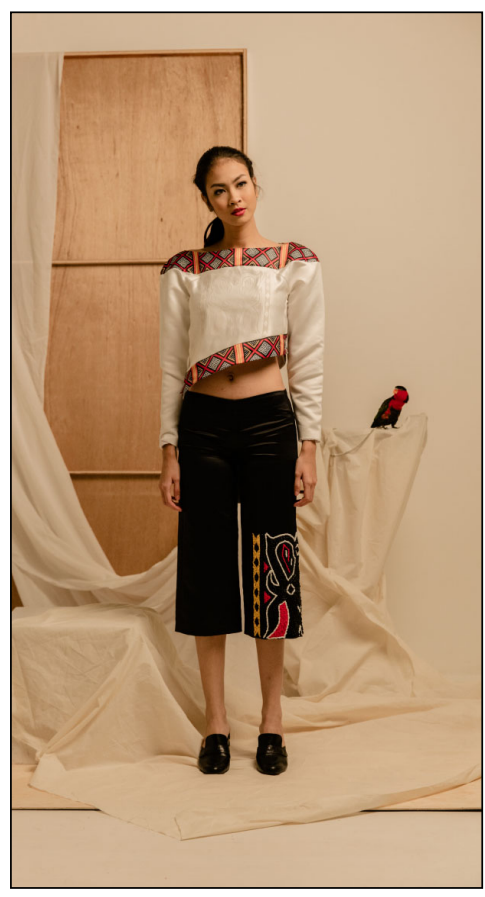

Gambar 11. PhotoshootDesain I Sumber: dokumentasi penulis, 2016

\section{Tampilan Desain II}

Tampilan kedua terdiri dari dua potong busana yaitu atasan dan celana panjang. Bahan yang digunakan adalah taffeta bridal.Atasan tangan setali dibuat dengan potongan asimetris yang terinspirasi dari siluet baju adat pria Toraja. Penempatan ilustrasi motif Pa'sekong Kandaure diletakkan pada atasan bagian depan dan belakang berbentuk asimetris menyerupai selendang baju adat pria. Pewarnaan motif Pa'sekong Kandaure menggunakan teknik digital printing.Bagian kain putih ditempatkan motif Pa'tedong yang disablon flock.

Celana panjang dibuat dari bahan taffeta bridal dengan pewarnaan motif Pa'sekong Kandaure dan $\mathrm{Pa}^{\prime}$ tedong menggunakan teknik digital printing. Ilustrasi motif Pa'sekong Kandaure ditempatkan pada bagian sisi depan celana panjang. Ilustrasi dua motif Pa'tedong ditempatkan pada bagian tengah depan, dengan penerapan teknik beads pada motif. Pada bagian sisi belakang celana panjang ditambahkan aksen dari motif Pa'tedong. 


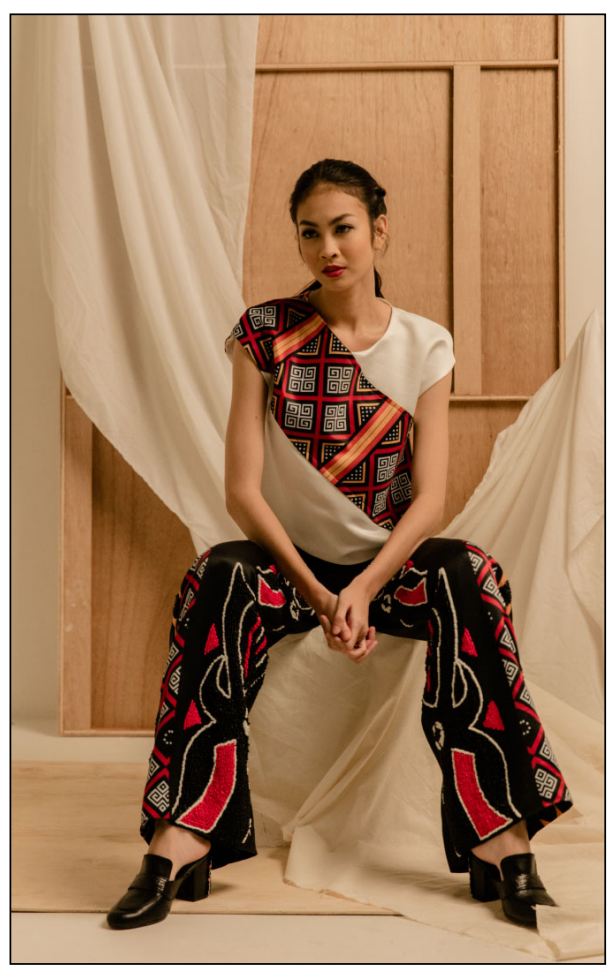

Gambar 12. PhotoshootDesain II Sumber: dokumentasi penulis, 2016

\section{Tampilan Desain III}

Tampilan ketiga terdiri dari dua potongan busana yaitu atasan dan rok.Bahan yang digunakan adalah taffeta bridal.Atasan tangan panjang dibuat dengan potongan crop topberlengan panjang.Pewarnaan menggunakan teknik digital printing berwarna hitam. Ilustrasi Pa'tedong ditempatkan di sekeliling bagian bawah crop top dengan tambahan beads pada motif.

Rok dibuat dari bahan taffeta bridal dengan penempatanilustrasi potongan motif ukiran Pa'sekong Kandaure pada bagian kedua sisi. Pewarnaan menggunakan teknik digital printing yang di bagian tengah depan rok ditempatkan motif Pa'tedong yang disablon flock. 


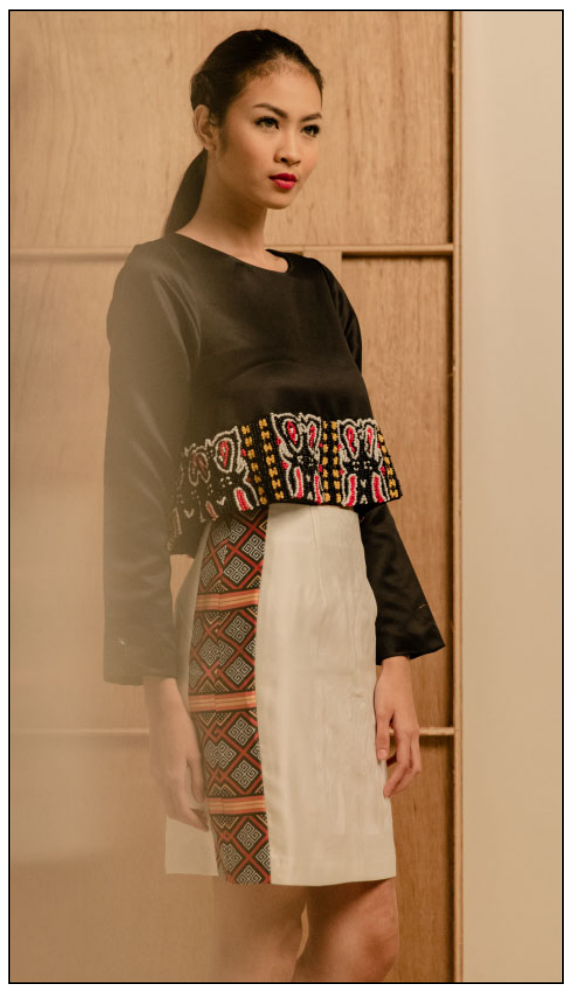

Gambar 13. PhotoshootDesain III Sumber: dokumentasi penulis, 2016

\section{Tampilan Desain IV}

Tampilan keempat terdiri dari dua potong busana yaitu atasan lengan panjang dan rok panjang.Secara keseluruhan bahan yang digunakan adalah taffeta bridal.Ilustrasi Pa'tedong ditempatkan pada atasan dan motif ditempatkan menumpuk serta lebih panjang. Motif Pa'tedong ditambahkan dengan pengaplikasian beads pada bagian depan atasan. Pada bagian belakang atasan dibuat bertumpuk tetapi tidak ada motif.

Rok panjang dibuat bersiluet lurus dari bahan taffeta bridal.Ilustrasi potongan motif ukiran Pa'sekong Kandaure ditempatkan pada bagian tengah bawah rok.Pewarnaan menggunakan teknik digital printing. Pada bagian tengah rok depan ditempatkan motif Pa'tedong yang disablon flock. 


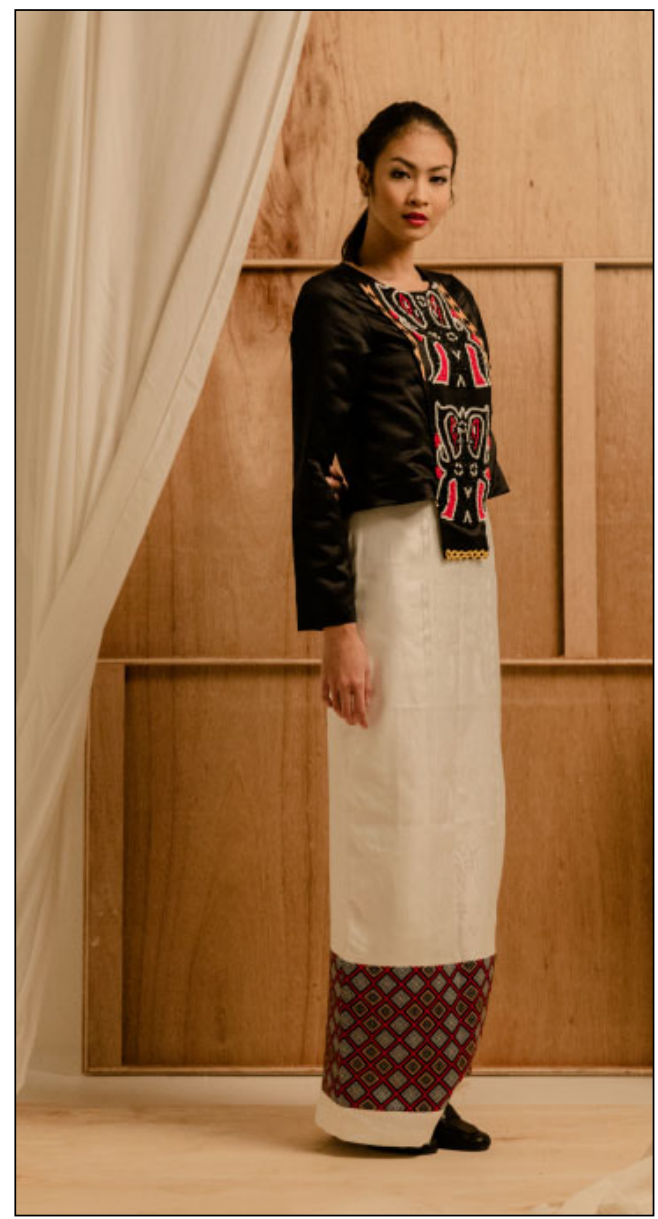

Gambar 14. Photoshoot Desain IV Sumber: dokumentasi penulis, 2016

Adapun aksesori sebagai pelengkap koleksi iniberupa sepatu sandal yakni desain pertama, sepatu sandal berwarna hitam dengan penempatan teknik beads pada bagian hak sepatu sandal dengan hiasan garis sekitar $3 \mathrm{~cm}$ dan desain kedua, sepatu sandal berwarna hitam dengan penempatan teknik beads pada bagian muka ditambah lapisanlidah seperti loafers.

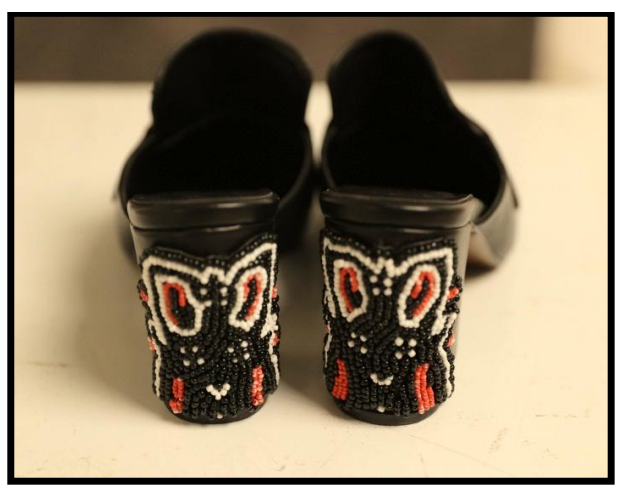


Gambar 15. Desain I aksesori (sepatu sandal) Sumber: dokumentasi penulis, 2016

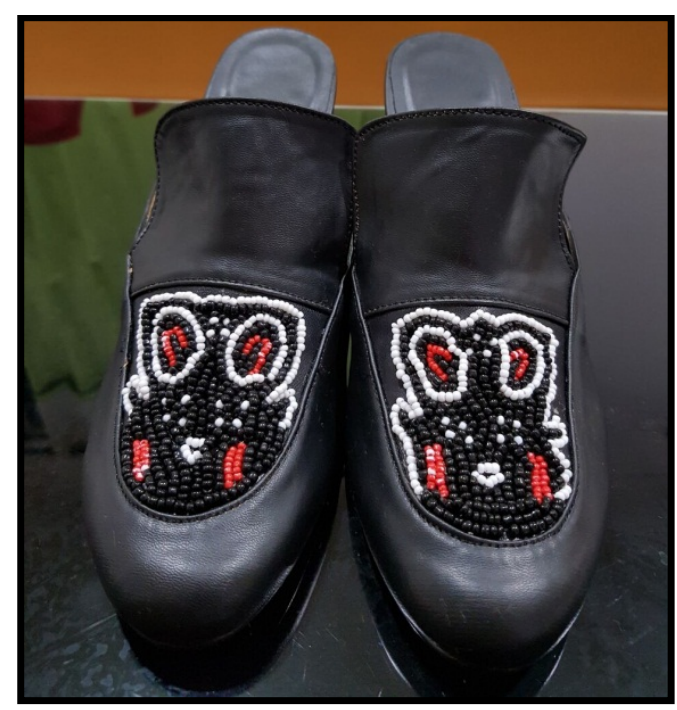

Gambar 16. Desain II aksesori (sepatu sandal) Sumber: dokumentasi penulis, 2016

Keempat koleksibusana ready-to-wear deluxe "Pa'surra Toraya" tersebut dirancang untuk mengangkat motif ukiran Toraja yang berkarakter etnik modern sebagai penunjang self statementbagi kalangan wanita urban yang senantiasa aktif, dinamis, dan memiliki mobilitas tinggi tanpa melupakan budaya/ tradisi Indonesia.

\section{PENUTUP}

Koleksi busana ready-to-wear deluxe Pa'surra Toraya menerapkan motif ukiran Toraja yakni Pa'tedong dan Pa'sekong Kandaure.Referensi sekaligus batasan desain dari koleksi ini berdasarkan tema Vigilant dan subtema Numericraft yang dipaparkan dalam buku Trend Forecasting 2017-2018 Grey Zone.

Perancangan busana berkonsep etnik modern ini diharapkan dapat meningkatkan animo masyarakat urban yang semakin modern gaya hidupnya untuk tetap mengenal bahkan mencintai budaya atau tradisi Indonesia, dalam hal ini adalah ukiran Toraja. 
Kendala penerapan teknik beads dan sablon flock dalam koleksi ini merupakan hal yang sangat perlu mendapatkan perhatian dari segi teknis karena selain memerlukan craftsmanship yang tinggi (dalam memperhitungkan ukuran kepadatan ruang penempatan beads) juga perhitungan waktu pembuatan dengan segala kemungkinan risiko gagal yang mungkin terjadi.

\section{DAFTAR PUSTAKA}

Ernawati, dkk. (2008). Tata Busana Jilid I Untuk Sekolah Menengah Kejuruan. Jakarta: Direktorat Pengembangan Sekolah Menengah Kejuruan.

Muhammading, Sahriah. (1998). Laporan Hasil Penelitian Museum Negeri Propinsi Sulawesi

Selatan: Benda-Benda Sejarah Peninggalan Kerajaan Wajo dan Soppeng. La Galigo: Museum Negeri Propinsi Sulawesi Tengah.

Tim perancang mode Indonesia. (2016). Trend Forecasting 2017-2018:"Grey Zone". Jakarta: BeKraf.

\section{Sumber Online}

http://tekateki1234.blogspot.co.id/2015/07/pakaian-adat.html, diakses 11 November 2016 pukul 17.09 WIB.

http://www.budaya-indonesia.org/Pakaian-Adat-Suku-Toraja/ diakses pada 11 November 2016 pukul 17.09 WIB.

http://www.kelasbusana.com/2016/01/pengertian-busana-jenis-dan-fungsinya.html, diakses pada 5 April 2017 pukul 10.30 WIB.

http://www.tanatorajakab.go.id/id/content/letak-geografis, diakses pada 5 April 2017 pukul 10.30 WIB.

http://www.torajaparadise.com/2015/02/kajian-antropologis-suku-toraja-sebuah.html, diakses pada 5 April 2017 pukul 10.30 WIB. 